\title{
Elusive effects of unemployment on happiness
}

\author{
Petri Böckerman \\ Labour Institute for Economic Research \\ and \\ Pekka Ilmakunnas \\ Helsinki School of Economics and HECER
}

Discussion Paper No. 47

February 2005

ISSN 1795-0562

HECER - Helsinki Center of Economic Research, P.O. Box 17 (Arkadiankatu 7), FI-00014 University of Helsinki, FINLAND, Tel +358-9-191-28780, Fax +358-9-191-28781, E-mail info-hecer@helsinki.fi, Internet www.hecer.fi 


\title{
Elusive effects of unemployment on happiness*
}

\begin{abstract}
This paper explores the connection between unemployment and subjective well-being in Finland by using cross-sections for the years 1990, 1996 and 2000 from World Values Surveys. An unprecedented increase in the national unemployment rate (from 3 to 17 per cent) did not produce a drop in the mean level of subjective well-being. Experiencing unemployment personally reduces life satisfaction, but does not have a significant effect on happiness in ordered logit estimation. However, generalized ordered logit estimation that allows the explanatory variables to have different effects on the odds of different happiness levels reveals that being unemployed has a negative effect on happiness at lower happiness scores, but no significant effect at high happiness levels.
\end{abstract}

JEL Classification: I31, J64

Keywords: happiness, unhappiness, life satisfaction, unemployment

Petri Böckerman

Labour Institute for Economic Research

Pitkänsillanranta $3 \mathrm{~A}$

FI-00530 Helsinki

FINLAND

e-mail: petri.bockerman@labour.fi
Pekka Ilmakunnas

Department of Economics Helsinki School of Economics

P.O. Box 1210

FI-00101 Helsinki

FINLAND

e-mail: pekka.ilmakunnas@hkkk.fi

* We are grateful to Heikki Ervasti, Ulla Hämäläinen, Jukka Pirttilä, Olli-Pekka Ruuskanen, Hannu Tanninen and Roope Uusitalo for comments. The usual disclaimer applies. 


\section{Introduction}

There are two broadly accepted stylized facts discovered in the empirical literature on happiness (Frey and Stutzer 2002). The first one is that married people are happier. The second one is that experiencing unemployment personally makes one very unhappy (e.g. Clark and Oswald 1994; Winkelmann and Winkelmann 1998; Di Tella et al. 2001). ${ }^{1}$ Do these facts really hold always and everywhere? The purpose of this paper is to analyze the determinants of subjective well-being in Finland, in particular the connection between subjective well-being and unemployment. The national unemployment rate rose very rapidly from 3 to 17 per cent in the early 1990 s. One would therefore expect that there has been a considerable drop in happiness. ${ }^{2}$

There are, however, factors that may weaken this connection. First, high unemployment reduces the social stigma associated with the experience of unemployment (e.g. Lindbeck et al. 1999). The social stigma can also weaken through habituation effects while one is unemployed over a long period of time. This point is relevant, because the relatively high unemployment rate has persisted in Finland since the great slump of the early 1990s. Second, the level of unemployment benefits and other social benefits is high in Finland in comparison with many other countries, in particular the UK, where much of the evidence on the connection between happiness and unemployment originates from. This means that the positive correlation between unhappiness and unemployment can be somewhat weaker in a Nordic welfare state such as Finland, because the economic consequences of being unemployed are mitigated by the presence of social insurance and consequent income transfers. Third, unemployment is somewhat more concentrated in Finland among older people (aged 55-64) than is the average figure for the European Union. The ratio of the unemployment rate for those aged 25-54 compared with those aged 55-64 is, on average, 0.88 for the European Union. The same figure for Finland is 1.11 (OECD, 2003). This feature of the labour market may further weaken the connection between happiness and unemployment, because unemployment does more harm to young people in terms of permanent losses of future earnings. In addition, local rather than national unemployment may matter for one's happiness. Again, this is interesting in the Finnish context, because the regional disparities of the unemployment rates in Finland are among the highest in the whole of the European Union (OECD, 2000), and they have substantially increased during the 1990s. 
The rest of the paper is structured as follows. Section 2 provides a description of the data. Section 3 reports the results. Section 4 concludes.

\section{The data}

This study uses World Values Surveys for Finland for the years 1990, 1996 and 2000 (Gallup Finland 2004). The data set is not a panel, but three separate cross-sections. It provides two measures for the overall satisfaction level. The variable HAPPINESS is an answer to the question: "Taking all things together, would you say you are" 4 ("very happy'), 3 ('quite happy'), 2 ('not very happy'), or 1 ('not at all happy')". The variable LIFE_SATISFACTION is an answer to the question: "All things considered, how satisfied are you with your life as a whole in these days?". Life satisfaction is measured on a scale from 1 to 10 (a higher value means that a person is currently more satisfied with his/her life). The distributions of these variables are shown in Tables 1 and 2 . It is interesting to note that the mean level of life satisfaction has not reacted at all to the unprecedented increase in the national unemployment rate, and the same applies to happiness (see Figure 1). This is in sharp contrast with the findings reported by Di Tella et al. (2001) for 12 European countries ${ }^{3}$ over the period 1975-1991, according to which an increase in the general rate of unemployment produces a substantial decrease in life satisfaction. $^{4}$

\section{$===$ TABLES 1 AND 2 HERE $===$}

$===$ FIGURE 1 HERE $=======$

A dummy variable captures the current unemployment status (UNEMPLOYED, 9.4 per cent of all survey respondents). There has been a lot of debate in the literature about the relevance of income in the determination of happiness (e.g. Veenhoven 1993; Easterlin 2001). The income variable that is possible to construct for all years is LOW_INCOME, which is a dummy for persons whose income is within the lowest three income groups. ${ }^{5}$

We include a wide set of control variables. These include personal characteristics, a dummy for females (FEMALE), age and its square (AGE and $\mathrm{AGE}^{2}$ ), and the level of education (dummy BASICED for only comprehensive education and HIGHED for 
university degree). Human relationships are captured by dummy variables for married (MARRIED), widowed (WIDOWED) and divorced (DIVORCED) people, and the number of children is captured as a continuous variable (CHILDREN). Religious activity which is likely to affect life satisfaction (e.g. Helliwell 2003) is captured by two variables (dummy $\mathrm{CHURCH}$ for going to church at least once a month, and GOD, an answer to the question: "How important is God in your life?", on a scale from 1 to 10). The labour market attachment is measured by a dummy variable for people working less than 30 hours per week (PART_TIME). In addition, we have dummy variables for entrepreneurs (ENTREPRENEUR), retired (RETIRED), students (STUDENT), housewives (HOUSEWIFE), managers (MANAGER) and main earners in the household (MAIN_EARNER).

For the year 2000 we have additional explanatory variables. As for unemployment, we have a dummy variable for those who have been unemployed for over one year (LONGTERM_UN, 7.5 percent of respondents) and the regional unemployment rate (UN) in 21 NUTS3 regions. We also have two new measures for income, the logarithm of the midpoints of self-reported net monthly wage groups (INCOME) and relative income (RELATIVE_INCOME), which is the residual of a wage equation where INCOME is explained by FEMALE, AGE, AGE ${ }^{2}$, BASICED, HIGHED, MARRIED, FULL_TIME, PART_TIME, ENTREPRENEUR, RETIRED, MANAGER, UNEMPLOYED, LONGTERM_UN and UN. Clark and Oswald (1996), among others, argue that it is the relative income that matters for one's happiness.

\section{The results}

\subsection{Basic results}

The ordered logit estimation results for the pooled data are reported in Table 3 . The robust z-statistics account for clustering by year, i.e. the error terms are allowed to be correlated within a survey year. The reference group in these estimations consists of persons who are in paid work for over 30 hours per week, are male with medium level education, single without previously being married, do not go to church, are not managers, are secondary earners in the family, and have high incomes. Thus, the unemployed are compared with persons with a strong attachment to the labour market. ${ }^{6}$ 
The results show that unemployment reduces life satisfaction, while having an insignificant effect on happiness. Low income has a clear negative effect on both happiness and life satisfaction. One interpretation of the result on unemployment and happiness is that society has adapted itself to the persistent high unemployment that emerged during the great slump of the early 1990s. It is possible that the social stigma associated with experiencing unemployment personally may have gradually melted away over time, although unemployment may still affect happiness negatively through low income. On the other hand, the results for life satisfaction are somewhat different from the ones for happiness. Thus, the results seem to cast some doubt on studies that take the position that happiness and life satisfaction measure the same underlying thing. ${ }^{7}$

The results arising from the control variables reveal that Finnish females are not happier than males. Happiness and life satisfaction have a U-shape profile in terms of age, which is in line with the results for the UK and the US (Blanchflower and Oswald 2004). Higher education increases both happiness and life satisfaction and low education reduces them. Married people report a higher level of subjective well-being in line with the literature, and also a strong belief in God is associated with a higher level of happiness and life satisfaction. Part-timers have lower life satisfaction, and housewives and managers are happier. Both happiness and satisfaction are higher in 1996 and 2000 than in 1990.

\subsection{Robustness of the results}

Can the results be driven by restrictive assumptions of the estimated model? We have used an ordered model that rests on the parallel regression assumption, i.e. that the explanatory variables have the same impact on the odds of all of the ordered scores. The cumulative probability of having score $j$ or lower is $\operatorname{Pr}(y \leq j)=F\left(\tau_{j}-x \beta\right)$ where $y$ is the survey answer, $F$ cumulative logistic distribution, $\tau_{j}$ the cut-off value between scores $j$ and $j-1, x$ explanatory variables and $\beta$ the parameters that are the same for all the scores. 
This means that the log of the odds that the score is less than or equal to $j$ versus greater than $j$ is $\ln [\operatorname{Pr}(y \leq j) / \operatorname{Pr}(y>j)]=\tau_{j}-x \beta$. An alternative is the generalized ordered logit model, where the parameters are allowed to vary across categories (e.g. Long and Freese 2003). In this case, the log of the odds is $\ln \left[\operatorname{Pr}(y \leq j) /(\operatorname{Pr}(y>j)]=\tau_{j}-x \beta_{j}\right.$.

In the case of happiness, there are 4 different ordered alternatives, so that there are three sets of slope coefficients in the generalized model. It turned out that there were so few observations at the lowest happiness level that some of the coefficients could not be estimated. Therefore we aggregate the happiness scores 1 and 2 into one group, so that we have two sets of slopes to estimate.

In the generalized ordered logit estimates unemployment has a significant negative effect in the equation that determines the choice between the combined category $1 \& 2$ and category 3 (Table 3 ). However, it is insignificant in the second equation, which determines the choice between categories 3 and 4. Interestingly, low income has an insignificant effect in the first equation, whereas it is negative and significant in the second one. It seems that when people are very happy, unemployment does not reduce their happiness, whereas the moderately happy are likely to become even less happy. One interpretation of this result is that there is a subsistence level in happiness that is more or less the same for all human beings. Individuals become really unhappy if their level of happiness slips below that bottom threshold. This is most likely to happen for those persons who are already unhappy, when a miserable event such as unemployment strikes them. Low income, in turn, does not decrease the happiness of those who are already unhappy, but tends to decrease the happiness of the happiest people. In this sense, money matters more for the happiest.

In Table 4 we present the marginal effects of being unemployed on the probabilities of happiness scores from ordered logit and generalized ordered logit models. The table also presents the marginal effects of having low income. For comparability, the ordered logit results are also based on a three-category model, the coefficients of which are not reported, since the results were similar to those presented in Table 3 for 4-group classification. The confidence intervals have been calculated with bootstrapping (100 replications, with independent samples each year). The figures confirm our findings 
from Table 3. Unemployment has an insignificant marginal effect on happiness in ordered logit, but in generalized ordered logit the marginal effect on the probability of the combined group $1 \& 2$ is positive and that on group 3 negative. The marginal effect on the highest happiness group is insignificant. Low income, in turn, has, in ordered logit estimation, a significant and positive marginal effect on the probabilities of groups $1 \& 2$ and 3, and a negative effect on the probability of group 4. In generalized ordered logit the marginal effect on the lowest group (1\&2) is not significant.

$===$ TABLE 4 HERE $===$

As to the other explanatory variables, high education, religiousness and being a housewife have the same kind of effect as in ordered logit. The age variables are significant only in equation 2 of generalized ordered logit. Being an entrepreneur or being a manager has a significant, positive effect in the second equation. (Blanchflower, 2004, also finds entrepreneurs to be happier.) Being retired has a negative effect at low satisfaction levels, whereas a positive affect at the high satisfaction levels.

Proceeding in the same way as in the case of life satisfaction we aggregate scores 1,2 , 3 , and 4 into one group and estimate a generalized ordered logit with six sets of coefficients. The results (not reported) show that even there at the lowest satisfaction scores unemployment reduces satisfaction more clearly, whereas at the highest scores the effect is not significant.

We briefly summarize the key results for the year 2000 without presenting them in the tables. The ordered logit results reveal that being unemployed, being long-term unemployed, and regional unemployment are insignificant in the ordered logit model for happiness. ${ }^{8}$ Actual income and relative income do not have a significant effect, either. When the happiness equation for three categories is estimated with generalized ordered logit, being unemployed has a significant negative effect in the first equation, but an insignificant effect in the second. The other unemployment variables are still insignificant. The income variables are significant and positive in the second equation. These results support our findings obtained from the pooled data. 


\section{Conclusions}

This paper explored the connection between unemployment and subjective well-being in Finland by using cross section data from World Values Surveys for the years 1990, 1996 and 2000. There was an unprecedented increase in the national unemployment rate (from 3 to 17 per cent) during the early 1990s. Interestingly, this dramatic change in the overall labour market conditions did not produce a drop in the mean level of Finns' subjective well-being. Personally experiencing unemployment reduces life satisfaction, but unemployment and happiness are not related.

However, the result that unemployment and happiness are unrelated is caused by an artefact of the restrictions imposed in ordered logit estimation. Generalized ordered logit estimation, where the parallel regression assumption is lifted, shows that unemployment has a significant negative effect on moving from low happiness levels to higher ones, where at high happiness levels it has an insignificant effect. This means that unemployment contributes to the inequality of subjective well-being among individuals. All in all, the results demonstrate that unemployment may not always matter for happiness, but when investigating the issue one should go beyond the average effects. 
References

Blanchflower D (2004) Self-employment: More May Not Be Better. Swedish Economic Policy Review 11(2): 15-73.

Blanchflower D, Oswald AJ (2004) Well-being Over Time in Britain and the USA. Journal of Public Economics 88(7-8): 1359-1386

Clark A, Oswald AJ (1994) Unhappiness and Unemployment. Economic Journal 104(2): 648-659

Clark A, Oswald AJ (1996) Satisfaction and Comparison Income. Journal of Public Economics 61(3): 359-381

Di Tella R, MacCulloch RJ, Oswald AJ (2001) Preferences Over Inflation and Unemployment: Evidence From Surveys of Happiness. The American Economic Review 91(1): 335-341

Easterlin R (2001) Income and Happiness: Towards a Unified Theory. The Economic Journal 111(2): 465-484

Ervasti H (2002) Unemployment, Subjective Well-being and Job-search: A Comparison of Denmark and Finland. Series B:24, Department of Social Policy, University of Turku

Feather N.T. (1990) The Psychological Impact of Unemployment. Springer, Heidelberg Frey BS, Stutzer A (2002) Happiness \& Economics. How the Economy and Institutions Affect Human Well-Being. Princeton University Press, Princeton

Gallup Finland (2003) World Values Surveys, 1990-1993, 1995-1997, 2000: Finnish material. Finnish Social Science Data Archive, Tampere

Helliwell J (2003) How's Life? Combining Individual and National Variables to Explain Subjective Well-being. Economic Modelling 20(2): 331-360 
Lindbeck A, Nyberg S, Weibull, JW (1999) Social Norms and Economic Incentives in the Welfare State. Quarterly Journal of Economics 114(1): 1-35

Long JS., Freese J. (2003) Regression Models for Categorical Dependent Variables Using Stata, Revised ed. Stata Press, College Station

OECD (2000) Employment Outlook. OECD, Paris.

OECD (2003) Employment Outlook. OECD, Paris.

Veenhoven R (1993) Happiness in Nations 1946-1992. Erasmus U. Press, Amsterdam

Winkelmann L, Winkelmann R (1998) Why Are the Unemployed So Unhappy? Evidence From Panel Data. Economica 65(1): 1-15. 
Figure 1. Unemployment, life satisfaction, and happiness in Finland

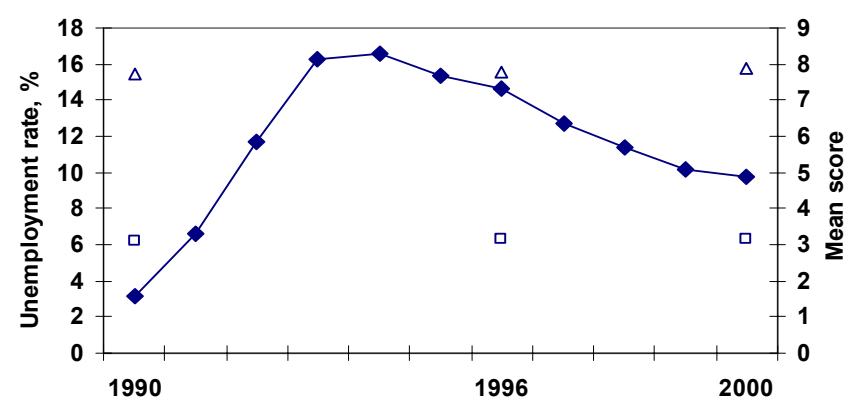

- Unemployment rate

$\Delta \quad$ Mean life satisfaction (scale 1-10)

口 Mean happiness (scale 1-4) 
Table 1. Distribution of happiness

\begin{tabular}{l|ll}
\hline & Number of obs. & Frequence (\%) \\
\hline 'Very happy' & 568 & 23.99 \\
'Quite happy' & 1587 & 67.02 \\
'Not very happy' & 181 & 7.64 \\
'Not at all happy' & 32 & 1.35 \\
\hline
\end{tabular}

Table 2. Distribution of life satisfaction

\begin{tabular}{l|ll}
\hline & Number of obs. & Frequence (\%) \\
\hline 1 & 10 & 0.42 \\
2 & 20 & 0.84 \\
3 & 38 & 1.6 \\
4 & 60 & 2.53 \\
5 & 116 & 4.9 \\
6 & 136 & 5.74 \\
7 & 334 & 14.1 \\
8 & 792 & 33.45 \\
9 & 615 & 25.97 \\
10 & 247 & 10.43 \\
\hline
\end{tabular}


Table 3. Ordered logit results for happiness and life satisfaction

\begin{tabular}{|c|c|c|c|c|}
\hline & \multirow{2}{*}{$\begin{array}{l}\text { Happiness, } \\
\text { ordered logit ( } 4 \\
\text { categories) }\end{array}$} & \multirow{2}{*}{$\begin{array}{l}\text { Life satisfaction, } \\
\text { ordered logit ( } 10 \\
\text { categories) }\end{array}$} & \multicolumn{2}{|c|}{$\begin{array}{l}\text { Happiness, generalized ordered logit } \\
\text { ( } 3 \text { categories) }\end{array}$} \\
\hline & & & Equation 1 & Equation 2 \\
\hline \multirow[t]{2}{*}{ UNEMPLOYED } & -0.165 & -0.371 & -0.807 & 0.183 \\
\hline & $(1.18)$ & $(3.86)^{* * *}$ & $(2.15)^{* *}$ & $(0.71)$ \\
\hline \multirow[t]{2}{*}{ LOW_INCOME } & -0.475 & -0.531 & -0.317 & -0.502 \\
\hline & $(5.76)^{* * *}$ & $(6.93) * * *$ & $(0.63)$ & $(7.29)^{* * *}$ \\
\hline \multirow[t]{2}{*}{ FEMALE } & 0.084 & 0.323 & 0.106 & 0.092 \\
\hline & $(0.57)$ & $(1.76)^{*}$ & $(0.44)$ & $(0.83)$ \\
\hline \multirow[t]{2}{*}{ AGE } & -0.128 & -0.097 & -0.114 & -0.131 \\
\hline & $(6.71)^{* * *}$ & $(6.00)^{* * *}$ & $(1.28)$ & $(6.14)^{* * *}$ \\
\hline \multirow[t]{2}{*}{$\mathrm{AGE}^{2}$} & 0.001 & 0.001 & 0.001 & 0.001 \\
\hline & $(7.22)^{* * *}$ & $(4.28) * * *$ & $(1.36)$ & $(6.01)^{* * *}$ \\
\hline \multirow{2}{*}{ BASICED } & -0.140 & -0.119 & -0.191 & -0.109 \\
\hline & $(2.17)^{* *}$ & $(5.70)^{* * *}$ & $(1.40)$ & $(1.52)$ \\
\hline \multirow[t]{2}{*}{ HIGHED } & 0.220 & 0.292 & 0.272 & 0.206 \\
\hline & $(3.79)^{* * *}$ & $(7.00)^{* * *}$ & $(3.83)^{* * *}$ & $(2.87)^{* * *}$ \\
\hline \multirow[t]{2}{*}{ MARRIED } & 0.996 & 0.516 & 0.919 & 1.04 \\
\hline & $(3.76)^{* * *}$ & $(2.63)^{* * *}$ & $(4.28)^{* * *}$ & $(3.22)^{* * *}$ \\
\hline \multirow{2}{*}{ WIDOWED } & 0.325 & 0.006 & 0.275 & 0.489 \\
\hline & $(0.87)$ & $(0.05)$ & $(2.22)^{* *}$ & $(0.76)$ \\
\hline \multirow[t]{2}{*}{ DIVORCED } & 0.075 & -0.136 & -0.108 & 0.326 \\
\hline & $(0.22)$ & $(0.59)$ & $(0.44)$ & $(0.86)$ \\
\hline \multirow[t]{2}{*}{ CHILDREN } & -0.014 & 0.008 & -0.027 & -0.004 \\
\hline & $(0.68)$ & $(1.70)$ & $(0.47)$ & $(0.65)$ \\
\hline \multirow[t]{2}{*}{$\mathrm{CHURCH}$} & 0.157 & 0.098 & -0.237 & 0.292 \\
\hline & $(0.56)$ & $(0.40)$ & $(1.61)$ & $(0.73)$ \\
\hline \multirow[t]{2}{*}{ GOD } & 0.053 & 0.096 & 0.084 & 0.038 \\
\hline & $(7.08)^{* * *}$ & $(5.88)^{* * *}$ & $(2.01)^{* *}$ & $(4.66)^{* * *}$ \\
\hline \multirow[t]{2}{*}{ PART_TIME } & -0.031 & -0.252 & 0.451 & -0.130 \\
\hline & $(0.09)$ & $(2.98) * * *$ & $(0.86)$ & $(0.35)$ \\
\hline \multirow[t]{2}{*}{ ENTREPRENEUR } & 0.199 & -0.096 & 0.362 & 0.208 \\
\hline & $(1.62)$ & $(0.54)$ & $(0.88)$ & $(2.51)^{* *}$ \\
\hline \multirow[t]{2}{*}{ RETIRED } & 0.051 & -0.115 & -0.947 & 0.604 \\
\hline & $(0.20)$ & $(0.39)$ & $(2.22)^{* *}$ & $(2.51)^{* *}$ \\
\hline \multirow[t]{2}{*}{ STUDENT } & 0.156 & 0.037 & 0.131 & 0.196 \\
\hline & $(0.50)$ & $(0.19)$ & $(0.45)$ & $(0.55)$ \\
\hline \multirow[t]{2}{*}{ HOUSEWIFE } & 0.677 & 0.072 & 17.803 & 0.761 \\
\hline & $(4.83)^{* * *}$ & $(0.45)$ & $(25.61)^{* * *}$ & $(4.63)^{* * *}$ \\
\hline \multirow[t]{2}{*}{ MANAGER } & 0.390 & 0.170 & -0.030 & 0.531 \\
\hline & $(3.04)^{* * *}$ & $(1.18)$ & $(0.28)$ & $(2.85)^{* * *}$ \\
\hline \multirow[t]{2}{*}{ MAINEARNER } & 0.069 & 0.186 & -0.434 & 0.224 \\
\hline & $(1.06)$ & $(1.14)$ & $(1.18)$ & $(2.46)^{* *}$ \\
\hline YEAR=1996 & 0.498 & 0.216 & 0.959 & 0.335 \\
\hline & $(8.66)^{* * *}$ & $(4.39)^{* * *}$ & $(6.81)^{* * *}$ & $(7.24)^{* * *}$ \\
\hline $\mathrm{YEAR}=2000$ & 0.440 & 0.352 & 0.564 & 0.412 \\
\hline & $(6.45)^{* * *}$ & $(5.18) * * *$ & $(4.79)^{* * *}$ & $(6.80)^{* * *}$ \\
\hline Observations & 2172 & 2172 & 2172 & \\
\hline Pseudo $\mathrm{R}^{2}$ & 0.056 & 0.029 & 0.075 & \\
\hline
\end{tabular}

Absolute values of robust $\mathrm{z}$ statistics in parentheses (adjusted for clustering by year).

$*$ significant at $10 \%$; * significant at $5 \%$;** significant at $1 \%$ 
Table 4. Marginal effects of UNEMPLOYED and LOW_INCOME on happiness

\begin{tabular}{|c|c|c|c|c|}
\hline & \multirow{2}{*}{$\begin{array}{l}\text { Marginal effect } \\
\text { of unemployment }\end{array}$} & \multicolumn{3}{|c|}{$95 \%$ bootstrap confidence interval } \\
\hline & & Normal & Percentage & Bias corrected \\
\hline $\begin{array}{l}\text { Ordered logit } \\
\operatorname{Pr}(\text { happiness }=1 \text { or } 2) \\
\operatorname{Pr}(\text { happiness }=3) \\
\operatorname{Pr}(\text { happiness }=4)\end{array}$ & $\begin{array}{l}0.011 \\
0.014 \\
-0.025\end{array}$ & $\begin{array}{l}(-0.021,0.043) \\
(-0.019,0.047) \\
(-0.089,0.039)\end{array}$ & $\begin{array}{l}(-0.019,0.042) \\
(-0.032,0.036) \\
(-0.081,0.051)\end{array}$ & $\begin{array}{l}(-0.019,0.042) \\
(-0.032,0.036) \\
(-0.081,0.051)\end{array}$ \\
\hline $\begin{array}{l}\text { Generalized ordered logit } \\
\operatorname{Pr}(\text { happiness }=1 \text { or } 2) \\
\operatorname{Pr}(\text { happiness }=3) \\
\operatorname{Pr}(\text { happiness }=4)\end{array}$ & $\begin{array}{l}0.038 \\
-0.071 \\
0.033\end{array}$ & $\begin{array}{l}(0.007,0.069)^{* *} \\
(-0.149,0.007) \\
(-0.042,0.108)\end{array}$ & $\begin{array}{l}(0.016,0.075)^{* *} \\
(-0.148,-0.002)^{* *} \\
(-0.040,0.101)\end{array}$ & $\begin{array}{l}(0.016,0.080)^{* *} \\
(-0.148,-0.002)^{* *} \\
(-0.040,0.101)\end{array}$ \\
\hline \multirow{2}{*}{$\operatorname{Pr}($ happiness $=4)$} & Marginal effect & \multicolumn{3}{|c|}{$95 \%$ bootstrap confidence interval } \\
\hline & & Normal & Percentage & Bias corrected \\
\hline $\begin{array}{l}\text { Ordered logit } \\
\operatorname{Pr}(\text { happiness }=1 \text { or } 2) \\
\operatorname{Pr}(\text { happiness }=3) \\
\operatorname{Pr}(\text { happiness }=4)\end{array}$ & $\begin{array}{l}0.036 \\
0.041 \\
-0.076 \\
\end{array}$ & $\begin{array}{l}\left(0.018,0.053^{* *}\right. \\
(0.022,0.059) \\
(-0.110,-0.043)^{* *} \\
\end{array}$ & $\begin{array}{l}(0.020,0.055)^{* *} \\
(0.025,0.060)^{* *} \\
(-0.108,-0.047)^{* *}\end{array}$ & $\begin{array}{l}(0.018,0.051)^{* *} \\
(0.024,0.060)^{* *} \\
(-0.108,-0.041)^{* *}\end{array}$ \\
\hline $\begin{array}{l}\text { Generalized ordered logit } \\
\operatorname{Pr}(\text { happiness }=1 \text { or } 2) \\
\operatorname{Pr}(\text { happiness }=3) \\
\operatorname{Pr}(\text { happiness }=4)\end{array}$ & $\begin{array}{l}0.012 \\
0.071 \\
-0.082\end{array}$ & $\begin{array}{l}(-0.003,0.027) \\
(0.024,0.117)^{* *} \\
(-0.127,-0.037)^{* *}\end{array}$ & $\begin{array}{l}(-0.001,0.030) \\
(0.022,0.116)^{* *} \\
(-0.125,-0.032)^{* *}\end{array}$ & $\begin{array}{l}(-0.0003,0.031) \\
(0.021,0.112)^{* *} \\
(-0.120,-0.030)^{* *}\end{array}$ \\
\hline
\end{tabular}




\footnotetext{
${ }^{1}$ Much of the psychological evidence on the negative effect of unemployment on subjective well-being is
} summarized in Feather (1990).

${ }^{2}$ In an earlier Finnish study, based on a special survey conducted in 1999, Ervasti (2002) reports that unemployment reduces the level of subjective well-being.

${ }^{3}$ The countries in the study by Di Tella et al. (2001) do not include Finland.

${ }^{4}$ On interpretation of this finding is that there is a trade-off between unemployment and inflation in people's utility (see Di Tella et al., 2001) and at the same time with the rise in unemployment, the inflation rate has fallen. The annual increases in the Finnish consumer price index in 1990, 1996, and 2000 were $6.1,0.6$, and 3.4 percent, respectively, so there may indeed have been a trade-off between inflation and unemployment in preferences. However, since we have only three time series observations we cannot test this trade-off.

${ }^{5}$ The income measures are different for different years of World Values Surveys. For the year 2000, net income was asked. For the year 1996 and for the year 1990, gross income is reported. In addition, for these particular years respondents are asked for either yearly or monthly income by using income groups and it is not possible to separate answers for yearly income from the ones for monthly income in order to construct a continuous variable for income.

${ }^{6}$ Broadening the reference group to include, in addition, those working in paid work for less than 30 hours and entrepreneurs did not change the results.

${ }^{7}$ Blanchflower and Oswald (2004), among others, advocate the position that the happiness equation and the life satisfaction equation have the same structure.

${ }^{8}$ These same results hold for life satisfaction. The result that being unemployed long-term does not hurt the level of happiness is robust to alternative specifications of being long-term unemployed. 